\title{
The Effect of E-Retail on Customer Satisfaction: Case Study from Jordan
}

\author{
Sharefa Murad ${ }^{\mathrm{a}}$, Esraa Nmr ${ }^{\mathrm{b}}$, Abdallah Qusef ${ }^{\mathrm{c}}$ \\ ${ }^{a}$ Computer Science Department, Middle East University, Amman, Jordan.E-mail: smurad@meu.edu.jo \\ ${ }^{b}$ Department of Software Engineering, Princess Sumaya University for Technology, Amman, Jordan. \\ E-mail: es.nmr2016@gmail.com \\ cDepartment of Software Engineering, Princess Sumaya University for Technology, Amman, Jordan. \\ E-mail: a.qusef@psut.edu.jo
}

Article History: Received: 11 January 2021; Accepted: 27 February 2021; Published online: 5 April 2021

\begin{abstract}
The increase in development and progress develops with the speed of the technology wheel and its impact on consumer satisfaction. Reasonably the electronic retail trade has the largest share. This research provides an abundant experience on the Jordanian consumer satisfaction with E- retail trade-in particular after customs facilities. The empirical study consists of 521 questionnaires and analysing the outputs, through which the sites are evaluated on more than one side, to come out with the most important strengths and weak points of the e-retail trade. Each question in the questionnaire is evaluated and assigned a unique loading factor. Four major evaluation metrics have been adopted to investigate the customer's thoughts on E-retail which includes Reliability, Design, Process, and safety. In addition, factor analysis of the Correlation Matrix with the samples sequence along with Goodness-of-fit indices have been carried out for the experimentation. The obtained insights from the empirical study are also validated using confirmatory factor analysis. Furthermore, to presenting problems with high rates to solve them.
\end{abstract}

Keywords: E-Retail, Quantitative Study, Customer Satisfaction.

\section{Introduction}

E-commerce plays an important role in daily life as it has become a large part of the wheel of the global and local economy [1-3]. Its impact is evident in the progress, development, and increase in revenue, as one of the studies indicated that E-commerce sales have been increased in Europe in 2015 to e 407 billion with a $15.6 \%$ increase comparing with 2014, and in the USA reached e 327 billion by the end of 2016 [4], also there are indicators that the value of E-commerce in the Arab nation in 2014 E-commerce was around $\$ 14$ billion, and it is predicted to reach more than $\$ 20$ billion in 2020 [5].

The consumer's satisfaction expresses the consumer's opinion about the good and the service provided, as it is the most essential component in the business that companies cannot exceed [6,7]. Customer satisfaction directly affects his intention to repurchase, as the greater the satisfaction the more the customer will increase the likelihood of requesting the product or service and thus increase his loyalty and shift from an ordinary customer to a permanent customer [8-10]. If the service providers or the product are unable to deliver to a good impression on the consumer and thus a lower level of satisfaction due to problems that will negatively affect the customer, complaint and frustration [11-13].

Vikram and Heena [14] mentioned that the disadvantages of E-retail: The conventional Retailers are providing lots of reductions and offerings which outlets are not able to offer like an instant replacement of faulty goods, free samples, discounts, etc.

The e-retailer business involves a massive amount of set-up, investment, logistics, and other fee processing costs. E- retailing is much less effective in many products and services especially the products for which touchfeel- smell is associated $[15,16]$.

As for the advantages, according to Vikram and Heena [14]: E-retailing allows the client to save cost and time. For buying online, clients aren't speculated to visit the shop physically. They also don't want to face in queue and watch for their turn. E-retailing has removed their tour time and cost.

E-retailing has facilitated the purchaser to shop-at-ease [17, 18]. It manner that they are able to do buying the way they prefer and in line with their choice. while doing buying online, the customer can concurrently do different important activities like cooking food, watching TV, discussing with circle of relatives members, etc [19, 20]. Eretailing design and development perspective structure is presented in the Figure 1. 


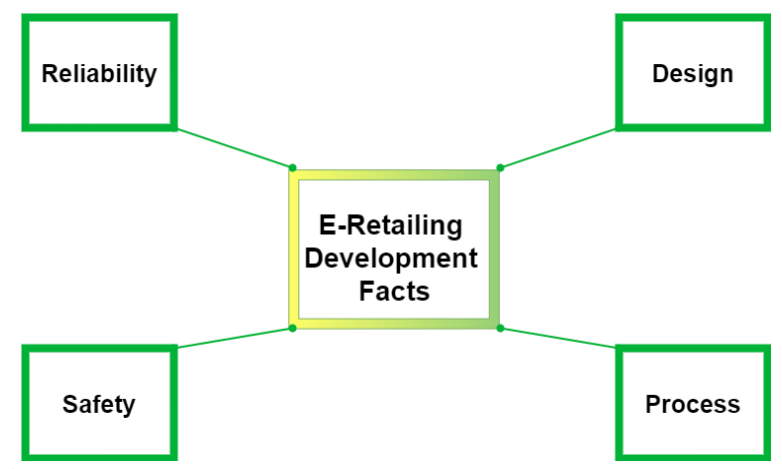

Figure 1. Structure of E-Retailing Design and Development Perspective

The clients can have get admission to to wider and deeper assortments at the same time as shopping online. They can also search for many different similar options available [21, 22]. Customers, through purchasing online, are in a role to customize the technique of buy consistent with their convenience.

Payments may be executed in unique approaches and how it's far handy for the clients [23-25]. E-retail trade as an important part of electronic commerce is receiving great attention to its many benefits including facilitating the purchase process for customers who do not have time for traditional shopping or a way to go to the market and providing products and services at any time as it expands the customer base and thus the possibility of increasing profits in addition to that, E-retail saves the cost a merchant faces in traditional commerce, e- retail in Jordan advanced [26]. The research aims to show consumer satisfaction in Jordan, especially on e-retail sites, after customs facilities, and highlight the real problems on the ground to try to improve them later [27].

In this research, the impact of customer satisfaction on E-Retail in Jordan has been measured. The observed study contains 521 surveys and interpreting the outputs, through which the sites are estimated on more than one side, to come out with the most significant concentrations and weak points of the E-retail enterprise. Each question in the questionnaire is assessed and allocated an individual loading factor. Four major evaluation metrics have been applied to examine the customer's thoughts on E-retail which includes Reliability, Design, Process, and safety. In addition, factor analysis of the Correlation Matrix with the samples sequence along with Goodness-offit indices have been carried out for the experimentation.

\subsection{Problem Statement}

The purpose of web-based retailing is expanding as time passes for any industry and in this manner offering an incentive to the client which thus likewise allow advantage to the retailer and separate it from the contenders is a significant task. By getting thought of how clients see and assess the contributions, retailers might have the option to impact the clients in that specific bearing.

Thus, there is a need to analyse customer satisfaction on a particular business for future sales forecasting. This analysis can lead the business to peak by diverting its internal approach in the light of the insights extracted from the analysis. The objectives of the research are as follow:

- To evaluate the impact of e-retail Process, Safety, Design and Reliability on overall customers in Jordan.

- To assess the influence of gender ration on the e-retailing in Jordan.

- To investigate the age-wise impact on the source of E-retailing in Jordan.

- To measure the co-relation of used evaluation metrics.

The remaining structure of the article is organized as Background and related work is described in Section 2. Where Section 3 consists of materials and methods reflecting the description of the conducted survey and the approaches used to obtain insights. Results and discussion along with experimental results and the visualization of the achieved insights are presented in Section 4. Finally, the manuscript is concluded in Section 5.

\subsection{Background}

Tahir and Guru [28] discussed the effect of customer satisfaction in terms of increasing customer spending in the American E-retail trade, the study highlighted on the most popular sites such as Amazon and E-bay, and another 113 leading e-retail websites in the United States of America; through the use of regression analysis based on a 
panel data model. The results showed that there is a positive relationship between customer satisfaction and its spending on websites.

Rasha and Emad [29] used the Technology Acceptance Model (TAM) and expanded it to include the trust of Technology and trust in the internet and the payment method to measure the factors that can influence the intention to buy from online stores in Jordanian community. The results showed that the Perceived Ease of Use (PEOU) has the highest impact on the intention to use than the trust in internet and technology and Perceived Usefulness.

The authors in [30], investigates the E-retailing influence on the specific way of website atmospheric manners. They considered usefulness, amusement, and adequacy of substance, to separate from several other studies. Their study endeavors e-satisfaction to interpret the impact of indulgent and pragmatic purchasing esteems and web barometrical signals. It is seen that web signals have a more noteworthy impact in forming e-satisfaction. Further, inside the information factors, the viability of data content has the biggest impact on e-satisfaction. The investigation likewise features the significance of the intervening job of e-satisfaction among reliability, shopping values, and site highlights.

Numerical analysis on the impact of after conveyance benefits on client impression of trust, repurchase intention and satisfaction are brought out by the authors in [31]. Information from 262 overview respondents, shows three basics after help factors, investigated by auxiliary condition modelling, identified with consumer discounts, returns, loyalty, and item trade. Studies additionally show noteworthy interceding impacts of consumer trust and loyalty with after conveyance administrations upon repurchase goal. Results uncover that consumer loyalty with administrations likewise intervenes in the connection between after conveyance administrations and shoppers' trust in the retailer.

In [32] reviews determinants that impact the value resilience of purchasers while purchasing various kinds of items on the web. The research utilizes the systematic order procedure to decide loads of all the impacting elements and afterwards decide their relative significance. Furthermore, the analysis reveals that the effect of satisfaction, trust, incentive on values, consumer loyalty, and resilience fluctuated by the idea of items. These outcomes confirm that the purchasers are more valuable tolerant to remote possessed e-retailers for purchasing electronic merchandise, presumably due to confidence in norms. The investigation has suggestions for the business managers, as it finds that trust and dependability are more significant variables than consumer loyalty and saw an incentive for e-retailing.

Another study [33] in Egypt has been carried out by the authors, about E-Service Quality's influence on ECustomer Satisfaction. The fundamental points of this examination are to research the critical factors involving low E-Customer Satisfaction in the bank. The research gathered 140 overviews from users who utilize online assistants in various departments of banks situated in Egypt. The determinant examination has indicated a remarkable effect on e-consumer loyalty and e-administration quality. The reverse investigation indicated a critical connection between all the factors of the e-consumer loyalty and e-administration quality with the exception of Compassion.

The authors conducted a thorough research study [34] to investigate essential factors of the administra- tion nature of E-Retailing of Islamic banks in KSA. The comfort test size comprises of 373 regular users of online Islamic financial offices in KSA. A four-factor E-SERVQUAL scale, for estimating the buyers' point of view; in a particular security, satisfaction, framework accessibility, and effectiveness was utilized. Confirmatory Factor Analysis and Exploratory Factor Analysis are employed to test the fitness of the model. Auxiliary condition modelling is used to decide the effect of E-administration quality measurements on clients' satisfaction. The outcomes of the investigation uncover that 1) consistent quality as an element of E-retailing of Islamic banks had a huge effect on clients' general satisfaction and there is a positive critical connection among responsiveness and clients' general accomplishment.

The comprehensive survey [35] adds to expanding comprehension of web-based retailing over e- channels touch-points from a buyer aspect. In light of the multichannel retailing strategy and hypothetical contemplations, the authors propose an upgraded aspect on the web-based retailing condition and approve this multichannel webbased business by leading both an online review with 502 samples and an exploratory examination with 126 samples. The outcomes show that web-based retailing can be arranged into four web- based business orders that involve accentuating the requirement for an increasingly separated thought, singular e-channel touch-points of "the online channel." Their work propels advertising exploration and practice by outlining that both innovation-related quality and setting related situational advantage influence purchasers' usage of e-channels. 
Table 1. Evaluation Metric Comparison with Previous Studies

\begin{tabular}{|c|c|c|c|c|c|c|}
\hline Studies & Design & Process & ReliabilityI & Integrity & Safety & Robustness \\
\hline$[28]$ & C & $C$ & $C$ & $\sqrt{ }$ & C & $\sqrt{ }$ \\
\hline [29] & $\checkmark$ & $\checkmark$ & $\checkmark$ & C & C & C \\
\hline [30] & ( & ( & ( & $\checkmark$ & C & $\checkmark$ \\
\hline [31] & $\checkmark$ & $\sqrt{ }$ & $\checkmark$ & $\checkmark$ & $\checkmark$ & ( \\
\hline [32] & ( & ( & C & $\sqrt{ }$ & C & $\sqrt{ }$ \\
\hline [33] & $\checkmark$ & $\checkmark$ & C & C & C & C \\
\hline [34] & ( & ( & ( & $\checkmark$ & C & $\sqrt{ }$ \\
\hline [35] & ( & ( & ( & $\checkmark$ & C & $\sqrt{ }$ \\
\hline [36] & ( & ( & $\checkmark$ & C & $\checkmark$ & C \\
\hline Ours & $\checkmark$ & $\sqrt{ }$ & $\checkmark$ & C & $\checkmark$ & ( \\
\hline
\end{tabular}

Another research [36] endeavours to explore the associations between online retail brand commitment, brand mindfulness, buying purpose, social linkages, brand trust, and the last brand choice. Their study also looks into likewise inspected the linkages among online retail brand commitment, brand mindfulness, buying purpose, social linkages, brand trust, and the last brand choice with the Indian online retail showcase. Data from 252 studies were examined utilizing the basic condition modelling technique. The result of their exploration study explains how a viable online retail brand commitment condition can be made to improve the current brand determination.

\section{Methodology}

The questionnaire was adopted as a method of data collection, to measure consumer satisfaction with e- retail in Jordan, and to know the most common problems facing the consumer. The evaluation criteria were classified into 4 main categories (Table 2). Each category included several key questions:

Table 2. Description of Evaluation Criteria Based on 4 Categories

\begin{tabular}{ll}
\hline Category & \multicolumn{1}{c}{ Evaluation aspects } \\
\hline Reliability & $\begin{array}{l}\text { The reliability of the information displayed on the site with the reality, the extent to which the } \\
\text { goods purchased are identical with the reality on receipt. }\end{array}$ \\
Design & $\begin{array}{l}\text { Ease of choice between products, order sequencing, site design efficacy, ease of use, and support } \\
\text { interfaces for multiple languages }\end{array}$ \\
Processes & $\begin{array}{l}\text { The speed of the purchase and response process, coordination between the selection, payment, } \\
\text { and delivery process and the provision of goods and services on the sites, the availability of } \\
\text { several methods of billing and delivery } \\
\text { Availability of privacy information on the site, availability of security requirements for the } \\
\text { payment process. }\end{array}$ \\
\end{tabular}

In addition, to asking about the difficulties and problems facing the e-retail trade in Jordan. The data will be analysed through Google form and statistical package for the social sciences (SPSS). The data was collected by a questionnaire, which was formulated by Google Form, and distributed via social media to several societal groups, housewives, learners, workers, students, and others to obtain results from several perspectives within a random sample. In this survey, 370 females and 151 males contributed to highlighting the most critical factors when eretailing from different web stores in Jordan. All the reviews were taken from the educated audience who are frequent users of online shopping. However, some of them are also adopted traditional way of retailing but in a low frequent manner. Table 3 summarizes the description of total participants

Table 3. Characteristics of Participants Involved in the Experiment

\begin{tabular}{lll}
\hline & Properties & Count \\
\hline Gender & male & 151 \\
Age & female & 370 \\
& Below 20 & 85 \\
& From 20 to 30 & 198 \\
Top used e-sites & From 30 to 40 & 61 \\
& Over 40 & 26 \\
& JollyChic, Facebook & 134 \\
& Modanisa & 68 \\
& Amazone, Alibaba & 24
\end{tabular}


The users buy from various E-retailing sites, for example, Facebook, Instagram, Amazone, Alibaba, Modanisa, Jolly Chic, Fordeal, Fire and Care, and other famous online stores. Along these lines, the original sample accounted to be illustrative of the number of inmates in the population. Description of Hypothesis the study seeks to test have been presented in Table 4.

The research aimed at diversity in the random sample and trying to reach a higher quality in terms of the information extracted. The results are based on an analysis of the 521 answer questions.

Table 4. Description of Hypothesis the Study Seeks to Test

\begin{tabular}{cl}
\hline \# & \multicolumn{1}{c}{ Hypothesis } \\
H2 & $\begin{array}{l}\text { Customs improvements will lead to high consumer satisfaction. } \\
\text { Through the continuous development of technology in Jordan, the use of e-retail, Jordanian websites } \\
\text { will increase }\end{array}$ \\
H3 & $\begin{array}{l}\text { The extent to which the displayed goods match reality after purchase increases will tend to increase in } \\
\text { consumer satisfaction }\end{array}$ \\
H4 & $\begin{array}{l}\text { The greater the common purchasing sequence by using the e-retail website, the greater the consumer } \\
\text { satisfaction. }\end{array}$ \\
H5 & $\begin{array}{l}\text { The effectiveness of the website design and arrangement with the ease of buying will lead to greater } \\
\text { consumer satisfaction }\end{array}$ \\
H6 & $\begin{array}{l}\text { Fast purchasing and response to the order impact on customer satisfaction. } \\
\text { The extent of coordination in the selection, payment, and delivery process will tend to increase in } \\
\text { consumer satisfaction. }\end{array}$ \\
H8 & $\begin{array}{l}\text { The availability of security requirements for the payment process on the site makes the customer more } \\
\text { satisfied. }\end{array}$ \\
H9 & $\begin{array}{l}\text { The availability of all goods and services on retail sites in Jordan makes the customer more satisfied. } \\
\text { The availability of the required information on the site makes the customer more satisfied. }\end{array}$ \\
H11 & $\begin{array}{l}\text { The availability of ways to communicate with the customer (chat, comment, recommendation) makes } \\
\text { the customer more satisfied } \\
\text { The availability of multiple payments and delivery methods makes the customer more satisfied. }\end{array}$ \\
H13 & $\begin{array}{l}\text { The availability of support interfaces for several languages within the website makes the customer } \\
\text { more satisfied. }\end{array}$
\end{tabular}

\section{Results and Discussion}

Four basic measures Reliability, Design, Process, and Safety were taken to conduct the confirmatory factor analysis [37]. Table 5 confers the model fit indices for the obtained measures mentioned in the Table 2.

The computed metrics as: normed-fit index $(\mathrm{NFI})=0.91$, mean square error of approximation $(\mathrm{RMSEA})=0.018$, Goodness of Fit $(\mathrm{GFI})=0.111$, comparative fit index $(\mathrm{CFI})=0.935, \mathrm{p}=.002$ (i.e. $\mathrm{p} ; 0.05$ ), and Goodness-of-fit indices such as CMIN/DF $=3.142$. shows better model fit indices. Structural model path coefficients on all Hypothesis are given in 7.

To assess the legitimacy of the current research, we estimated discriminant validity, concurrent validity, and scale dependability of the four measures such as Reliability, Design, Process, and Safety. The outcomes for scale validity are presented in Table 6 . The Table 6 shows satisfactory scale reliabilities with Composite unwavering quality (CR) of all components greater than 0.7 [38]. Similarly, the model obtained greater than 0.50 of the average variances extracted (AVE) for each dimension, demonstrating sufficient localized validity [38].

Factor Analysis of the Correlation Matrix with the samples sequence of (Process: Safety, Design: Reliability) is presented in Table 8. We can see from Table 8, the two-factor Correlation for Reliability vs (Design: Reliability) is -0.222 which shows the significant decrease in the belief of people of Jordan on the safety of on-line retailers in the perspective of Design and Reliability. Similarly, the two-factor Correlation for Design vs (Design: Reliability) is -2.085 which shows the greater decrease in the relativity design factor on the on-line retailers. There is a strong negative correlation that can be seen in the safety with -1.552 factor which interprets as the significant concerns of the people of Jordanians regarding safety on the online websites for online shopping.

We can observe from Table 7, that $\mathrm{H} 2, \mathrm{H} 8, \mathrm{H} 9, \mathrm{H} 10$ and $\mathrm{H} 11$ shows significant p difference with $\mathrm{p}_{i} 0.001$ and loading factor for H10 signifies 0.445 which shows that required information for any specific buying product should be there for the customer satisfaction. Furthermore, the least parameter which produce least impact on the 
customer sanctification is shown as $\mathrm{H} 12$ with 0.11 signification difference of $\mathrm{p}_{i} 0.01$. We can say that in Jordan, people do not care about the multiple payments' options.

The prominent results indicate that consumers in Jordan are generally satisfied with e- retail trade provided on the sites $63.1 \%$ (Figure 2). This validates Hypothesis 1 that customs developments have had an impact on consumer satisfaction especially in view of the abundance of products and services provided, the abundance of information on the site in addition to the ease of the purchasing process and it has improved over recent decades.

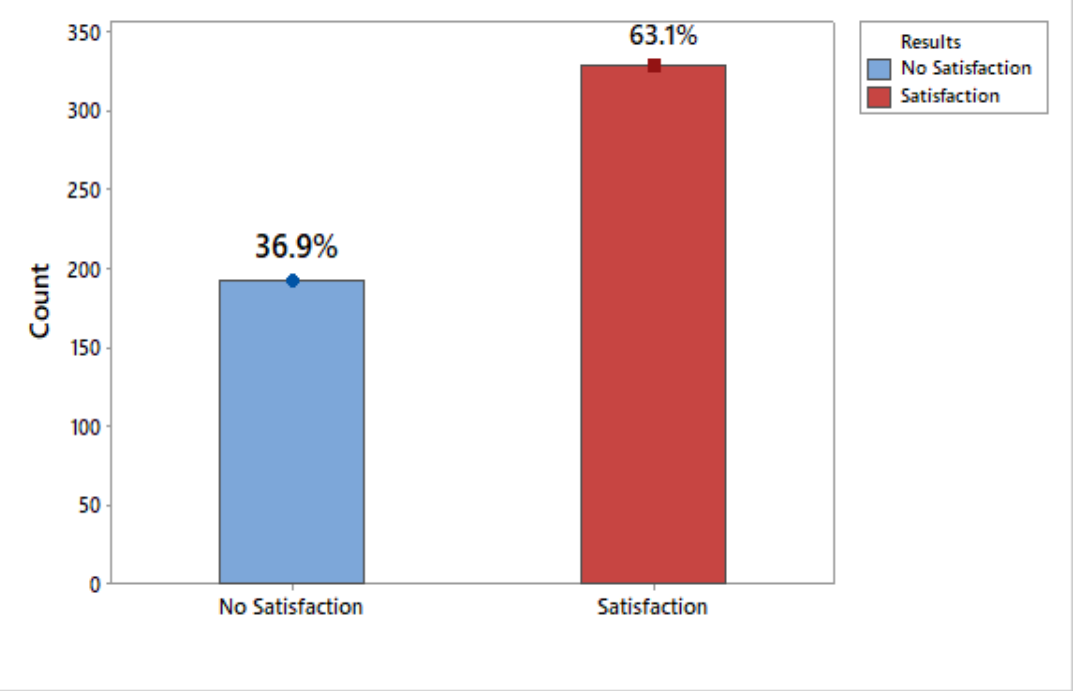

Figure 2. Visualization of Sample Evaluation in Terms of Satisfaction and No Satisfaction

Data analysis After Distributing the Questionnaire to Electronic Retail Customers Indicated the Following:

Table 5. Goodness-of-Fit Indices

\begin{tabular}{ccccccc}
\hline Index & CFI & GFI & NFI & \multicolumn{1}{c}{ P } & RMSEA & \multicolumn{1}{c}{ CMIN/DF } \\
\hline Standard Value & $>0.9$ & $>0.9$ & 0.9 & $<0.05$ & $<0.07$ & Between 1 to 5 \\
Obtained Value & 0.935 & 0.111 & 0.91 & 0.002 & 0.018 & 3.142 \\
\hline
\end{tabular}

Table 6. Results Obtained by Computing Validity and Reliability

\begin{tabular}{lccllll}
\hline & AVE & CR & Reliability & Design & Processes & Safety \\
\hline Reliability & 0.562 & 0.721 & 0.749 & & & \\
Design & 0.523 & 0.762 & & 0.723 & & \\
Processes & 0.594 & 0.779 & & & 0.770 & \\
Safety & 0.581 & 0.701 & & & & 0.762 \\
\hline
\end{tabular}

Table 7. Structural Model Path Coefficients on All Hypothesis

\begin{tabular}{lll}
\hline Hypothesis & Loading Factor & T-Statistic \\
\hline H1 & 0.579 & $4.15^{*}$ \\
H2 & 0.692 & $3.13^{* *}$ \\
H3 & 0.516 & $0.41^{*}$ \\
H4 & 0.588 & $0.82^{*}$ \\
H5 & 0.454 & $2.93^{*}$ \\
H6 & 0.872 & $51.90^{*}$ \\
H7 & 0.773 & $4.11^{*}$ \\
H8 & 0.852 & $1.44^{* *}$ \\
H9 & 0.810 & $1.02^{* *}$ \\
H10 & 0.445 & $5.51^{* *}$ \\
H11 & 0.793 & $2.65^{* *}$ \\
H12 & 0.322 & $0.11^{*}$ \\
H13 & 0.794 & $1.99^{*}$ \\
\hline
\end{tabular}

$* \mathrm{p}<0.01 \& * * \mathrm{p}<0.001$ 
Table 8. Factor Analysis of the Correlation Matrix with the Samples Sequence of (Process: Safety, Design: Reliability)

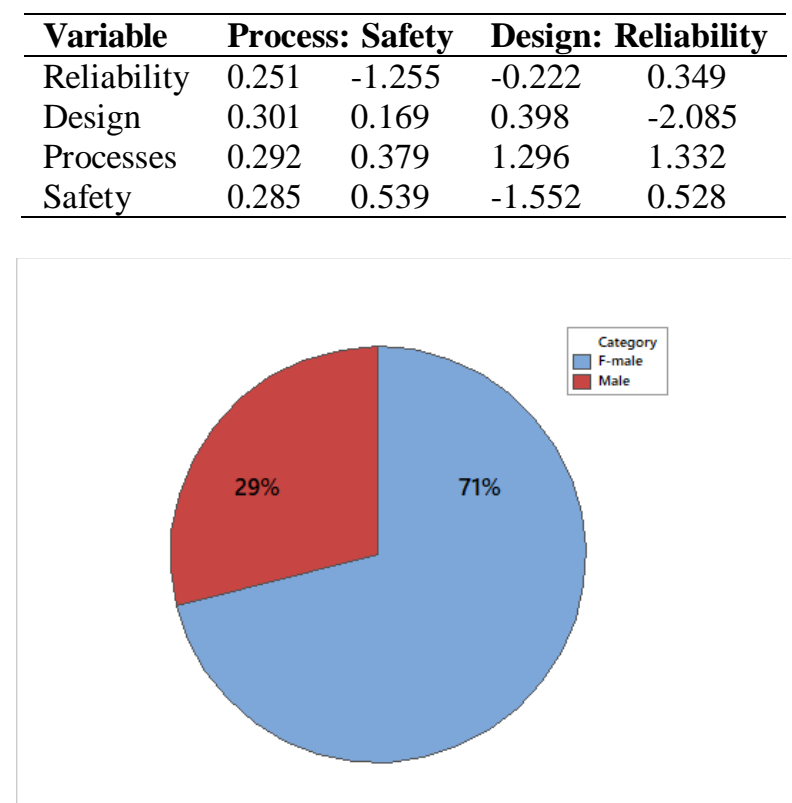

Figure 3. Gender Stats in E-Retail

1. Females occupy a higher percentage of males in terms of using the e-retail, reaching $71 \%$ (Figure 3 ), and this can be explained by another section in the questionnaire that includes answering the goods purchased through e-retail sites, which included cosmetics with $23 \%$ and utensils Household by $20 \%$.

2. The most used age group for electronic retail trade was between (20-30) at a rate of \% 55 while the age group (40 and above) was the least used as it reached $9.8 \%$, which means that electronic retail trade sites target their products and services to the youth category with more attention than the rest of the categories Other ages target its goods and services.

3. The consumer in Jordan did not rely heavily on Jordanian electronic retail sites, as the options for the sites used in electronic shopping were either Arab sites such as opensooq.com or foreign sites such as Amazon.com, and Madanisa.com.

Table 9. Obtained Descriptive Statistics

\begin{tabular}{lclll}
\hline & N & Range & Mean & St. dev. \\
\hline Reliability & 521 & 8 & 6.28 & 2.010 \\
Design & 521 & 16 & 13.88 & 3.858 \\
Processes & 521 & 16 & 13.62 & 3.807 \\
Safety & 521 & 8 & 6.75 & 2.138 \\
Valid N & 521 & & & \\
\hline
\end{tabular}

This indicates that there is no competitive advantage in the Jordanian electronic retail sites, which did not encourage the consumer to rely on them and abandon other sites in light of the global competition provided by electronic commerce. Where the satisfaction rate for the Jordanian electronic retail sites was 3.2 from 5 grades. This rejects $\mathrm{H} 2$.

Through the use of a program SPSS for the evaluation criteria matrix we find (Table 9): The evaluation reached an average score higher in terms of consumer satisfaction with the design of e- retail sites $13.88 \%$, which have ease of use, ease of purchase, support for more than one language, and design effectiveness.

The consumer evaluation of the process conducted on e-retail sites was also satisfactory $13.62 \%$ as consumers indicated through their answers to the speed of the purchase and response process, coordination between the purchase, delivery, shipping, and availability of goods on the site, and the availability of ways to communicate with the customer in several ways.

Safety assessment was not high in the consumer's view, as it reached $6.75 \%$ Which indicates a problem in terms of a sense of safety appropriately with the consumer towards his dealings with electronic retail sites, despite satisfactory previous indicators, there is still a gap in terms of safety-related to the presentation of safety 
information, especially on the site, and the provision of safety requirements for the payment process. This means that electronic commerce in Jordan still needs more safety guarantees and more secure payment methods.

The evaluation of reliability on e-retail sites was not satisfactory either, as it reached $6.28 \%$ This indicates that there is a significant problem that e- retail has not been able to overcome despite the efforts made by all websites to obtain consumer confidence and that the consumer is still not fully confident that the goods purchased will be identical to reality upon delivery, and that the information submitted on the site is $100 \%$ correct data. The ratio of male and female rating the safety measure of the online retails are presented visually in Figure 4. Furthermore, the age group consists of more than 40 years are not reliable with online shopping in Jordan (referred to as Figure 5).

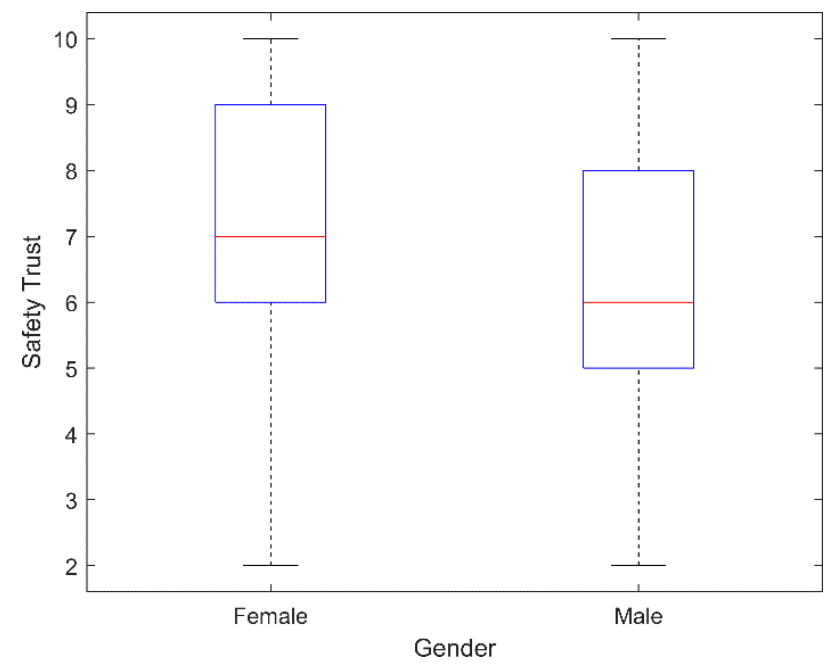

Figure 4. The Ratio of Male and Female Rating the Safety Measure of Online Retailing.

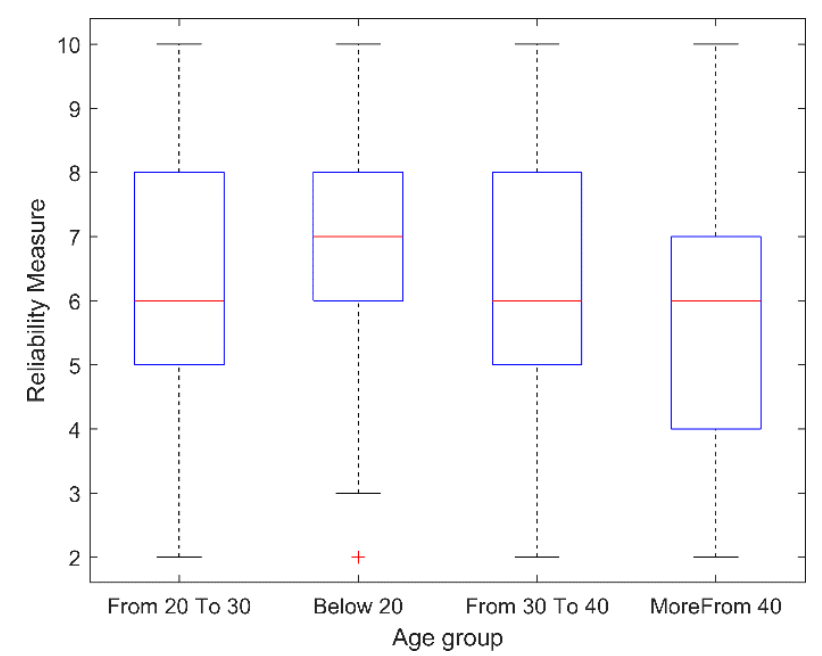

Figure 5. The Ratio of Different Age Groups Rating the Reliability Measure of Online Retailing.

Several problems have arisen within the e-retail trade in Jordan (Figure 6), through which it is recommended to find solutions to them, as these solutions will contribute to improving the level of satisfaction of the consumer further and deliver it to loyalty. The problems that were mentioned:

- Goods mismatch with reality after purchase.

- High delivery cost.

- The absence of an institution responsible for the Internet.

- Single payment method.

- Lack of accurate information on shipping.

- $\quad$ Product display is hidden for non-registered users.

- Static site in terms of updating products.

- Lack of confidence in the site. 


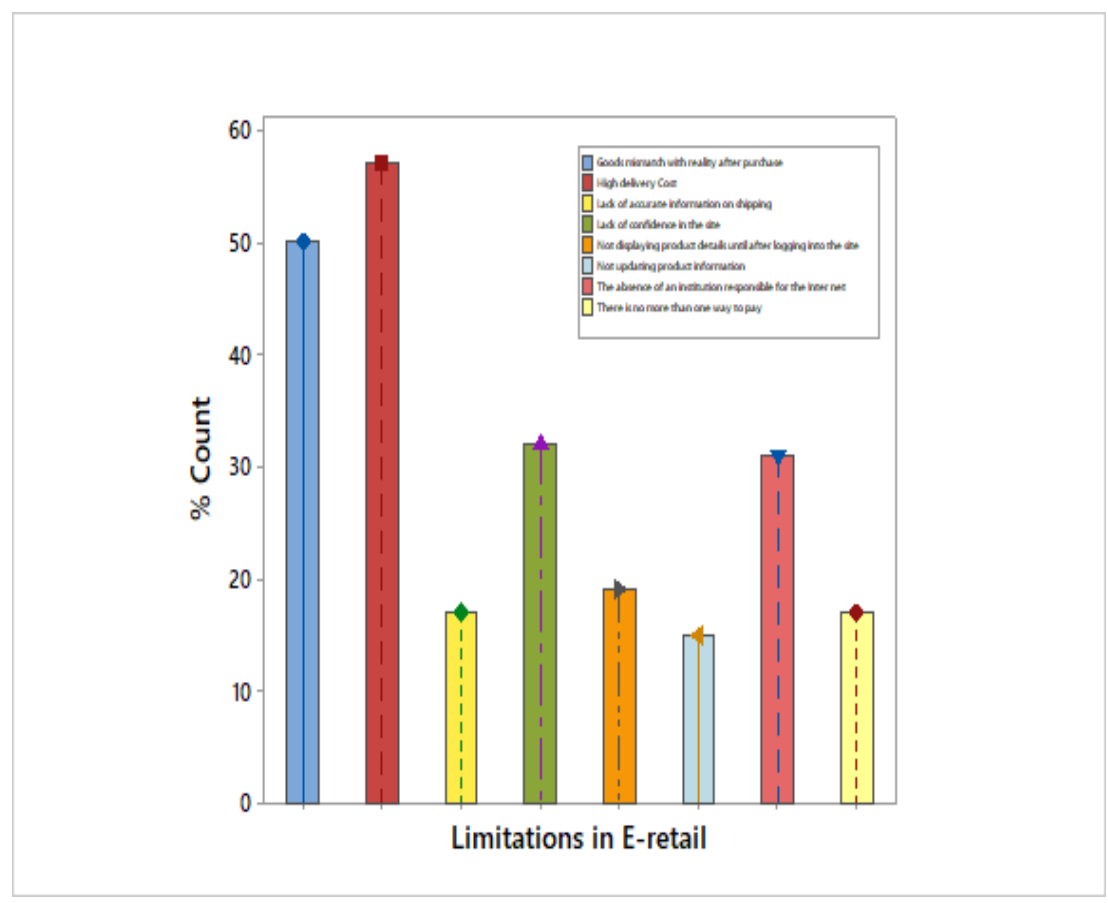

Figure 6. Problems in E-Retail

\section{Conclusions}

Advances in the world of e-commerce in general and e- retail, in particular, have had several effects on consumer satisfaction, which is the most profitable goal for a merchant. Each country seeks to improve e-retail trade in order to benefit more from it.

The research aims to measure consumer satisfaction with electronic retail trade through several axes, in an attempt to find a positive effect of customs facilities provided by the government. The data was collected by a questionnaire distributed to 521 consumers and analysed within Google Form and SPSS. The most prominent results indicated that there is a good satisfaction rate with the consumer, with a greater reliance on non-Jordanian E-retail sites. Females dominated the percentage of use, with the dominance of cosmetics and household items among the best sellers. Four influential evaluation metrics include Reliability, Design, Process, and safety have been used to examine the customer's opinions on E-retail. In addition, factor analysis of the Correlation Matrix with the samples sequence along with Goodness-of-fit indices have been carried out for the experimentation.

Satisfaction assessment was high in terms of design criteria and processes, which means that the consumer has no problem with website design and handling, nor does he find it difficult to sequence operations between choosing, buying and delivering. While the standards of system and reliability were lower in terms of evaluation, which indicates a problem of trust between the consumer and the website has not been resolved yet. At the end of the research, a recommendation was made to improve and reach higher value results.

\section{References}

1. Vazquez, E.E. (2019). Effect of e-retail product category on performance. In Predicting Trends and Building Strategies for Consumer Engagement in Retail Environments, IGI Global, 152-168.

2. Vakulenko, Y., Shams, P., Hellström, D., \& Hjort, K. (2019). Service innovation in e-commerce last mile delivery: Mapping the e-customer journey. Journal of Business Research, 101, 461-468.

3. Fauzi, F., Al-Khowarizmi, A.K., \& Muhathir, M. (2020). The e-Business Community Model is Used to Improve Communication Between Businesses by Utilizing Union Principles. Journal of Informatics and Telecommunication Engineering, 3(2), 252-257.

4. Skordoulis, M., Kaskouta, I., Chalikias, M., \& Drosos, D. (2018). E-commerce and e-customer satisfaction during the economic crisis. Journal for International Business and Entrepreneurship Development, 11(1), 15-29.

5. Hasan, L. (2016). Key Design Characteristics for Developing Usable E-Commerce Websites in the Arab World. Informing Science: The International Journal of an Emerging Transdiscipline, 19, 253-275. 
6. Alghaswyneh, O. (2014). The Impact of Implementing Customer Relationship Management in Umniah Mobile Company Jordan. European Journal of Business and Social Sciences, 2(10), 169-181.

7. Javid, E., Nazari, M., \& Ghaeli, M. (2019). Social media and e-commerce: A scientometrics analysis. International Journal of Data and Network Science, 3(3), 269-290.

8. Vakulenko, Y., Shams, P., Hellström, D., \& Hjort, K. (2019). Online retail experience and customer satisfaction: the mediating role of last mile delivery. The International Review of Retail, Distribution and Consumer Research, 29(3), 306-320.

9. Khandelwal, S.R.S.D.K. (2019). A Study on Customer Satisfaction Level Towards Online Retailing with Special Reference to Indore City. Journal Current Science, 20(4).

10. Ang, M., \& Chen, Y. (2020). Amazon: Facing low customer satisfaction in Singapore.

11. Tsai, H.T., Chien, J.L., \& Tsai, M.T. (2014). The influences of system usability and user satisfaction on continued Internet banking services usage intention: empirical evidence from Taiwan. Electronic Commerce Research, 14(2), 137-169.

12. Nawi, N.B.C., \& Al-Mamun, A. (2017). Customer satisfaction of online apparel businesses in Malaysia: point-purchase and post-purchase comparison. International Journal of Business Innovation and Research, 12(3), 386-405.

13. Khan, M.A., Zubair, S.S., \& Malik, M. (2019). An assessment of e-service quality, e-satisfaction and e-loyalty. South Asian Journal of Business Studies.

14. Sandhu, V., \& Atwal H. (2013). E-retail: its growth and prospects Radix. International Journal of Research in Social Science, 2(2), 1-18.

15. Kavitha, T.C., \& Rapoor, P.P. (2019). An Empirical Analysis on E-Retail Service Quality, 3PL in Supply Chain L-SQUAL, E-SQUAL and E-SRQUAL. International Journal of Supply Chain Management, 8(4), 1114-1120.

16. Agarwal, H., \& Dixit, S. (2020). From “e” Retail to “omni” Channel Retail: A Strategic Initiative of a Fashion Etailer. International Journal of Business Analytics (IJBAN), 7(2), 54-68.

17. Chou, Y.C., \& Shao, B.B. (2020). Adoption and Performance of Mobile Sales Channel for e-Retailers: Fit with M-Retail Characteristics and Dependency on e-Retailing. Information Systems Frontiers, 1-14.

18. Ashton, T., \& Prybutok, V.R. (2020). Developing and validating e-retailing satisfaction scales with textmining. Journal of Modelling in Management.

19. Jeeva, M.V., \& Kumar, A.R. (2020). A study on consumer satisfaction towards e-retailing," Our Heritage, $68(45), 35-46$.

20. Li, S. (2020). The impact of service quality, self-service technology, and the corporate image on customer satisfaction and customer revisit intention among luxury hotels in Kuala Lumpur, Malaysia. International Journal of Services, Economics and Management, 11(1), 48-70.

21. Donato, C., \& Raimondo, M.A. (2020). Tactile Sensations in E-Retailing: The Role of Web Communities. In Emotional, Sensory, and Social Dimensions of Consumer Buying Behavior, IGI Global, 225-247.

22. Tandon, A., Aakash, A., \& Aggarwal, A.G. (2020). Impact of EWOM, website quality, and product satisfaction on customer satisfaction and repurchase intention: moderating role of shipping and handling. International Journal of System Assurance Engineering and Management, 1-8.

23. Acquila-Natale, E., \& Iglesias-Pradas, S. (2020). How to measure quality in multi-channel retailing and not die trying. Journal of Business Research, 109, 38-48.

24. Zhou, M., Zhao, L., Kong, N., Campy, K.S., Xu, G., Zhu, G., \& Wang, S. (2020). Understanding consumers' behavior to adopt self-service parcel services for last-mile delivery. Journal of Retailing and Consumer Services, 52, 101911.

25. Lyu, F., \& Choi, J. (2020). The Forecasting Sales Volume and Satisfaction of Organic Products through Text Mining on Web Customer Reviews. Sustainability, 12(11), 4383.

26. Micu, A.E., Bouzaabia, O., Bouzaabia, R., Micu, A., \& Capatina, A. (2019). Online customer experience in e-retailing: implications for web entrepreneurship. International Entrepreneurship and Management Journal, 15(2), 651-675.

27. Al-dweeri, R.M., Moreno, A.R., Montes, F.J.L., Obeidat, Z.M., \& Al-dwairi, K.M. (2019). The effect of e-service quality on Jordanian student's e-loyalty: an empirical study in online retailing. Industrial Management \& Data Systems.

28. Nisar, T.M., \& Prabhakar, G. (2017). What factors determine e-satisfaction and consumer spending in ecommerce retailing?. Journal of retailing and consumer services, 39, 135-144.

29. Abu-Shamaa, R., \& Abu-Shanab, E. (2015). Factors influencing the intention to buy from online stores: An empirical study in Jordan. In IEEE 8th GCC Conference \& Exhibition, 1-6.

30. Vijay, S.T., Prashar, S., \& Sahay, V. (2019). The influence of online shopping values and web atmospheric cues on e-loyalty: Mediating role of e-satisfaction. Journal of theoretical and applied electronic commerce research, 14(1), 1-15. 
31. Javed, M.K., \& Wu, M. (2020). Effects of online retailer after delivery services on repurchase intention: An empirical analysis of customers' past experience and future confidence with the retailer. Journal of Retailing and Consumer Services, 54, 101942.

32. Pandey, N., Tripathi, A., Jain, D., \& Roy, S. (2019). Does price tolerance depend upon the type of product in e-retailing? role of customer satisfaction, trust, loyalty, and perceived value, Journal of Strategic Marketing, 1-20.

33. Shared, H.A. (2019). The relationship between e-service quality and e-customer satisfaction: An empirical study in Egyptian Banks. International Journal of Business and Management, 14(5).

34. Tabash, M.I., AlbugamI, M.A., Salim, M., \& Akhtar, A. (2019). Service quality dimensions of E-retailing of Islamic banks and its impact on customer satisfaction: An empirical investigation of kingdom of Saudi Arabia. The Journal of Asian Finance, Economics, and Business, 6(3), 225-234.

35. Wagner, G., Schramm-Klein, H., \& Steinmann, S. (2020). Online retailing across e-channels and echannel touchpoints: Empirical studies of consumer behavior in the multichannel e-commerce environment. Journal of Business Research, 107, 256-270.

36. Bhattacharya, S., \& Anand, V. (2020). An empirical study on the factors affecting online retail brand engagement and purchase intention. Malaysian Management Journal, 20, 111-129.

37. Ahmad, A., \& Khan, M.N. (2017). Developing a website service quality scale: A confirmatory factor analytic approach. Journal of internet Commerce, 16(1), 104-126.

38. Jiang, L.A., Yang, Z., \& Jun, M. (2013). Measuring consumer perceptions of online shopping convenience. Journal of Service management. 24(2), 191-214. 